SUSTAINABLE FORESTRY

COLLECTION 81-82, 2020
ODRŽIVO ŠUMARSTVO

ZBORNIK RADOVA 81-82, 2020

UDK 502.17+628.35=111

Original scientific paper

\title{
ENVIRONMENTAL ASPECTS OF BIOLOGICAL WASTEWATER TREATMENT BY DIFFERENT METHODS AND MICROORGANISMS
}

\author{
Tatjana VIJATOV ${ }^{I}$, Gordana DRAŽIĆ ${ }^{1}$, Filip JOVANOVIĆ ${ }^{2}$
}

\begin{abstract}
The biological treatment of wastewaters (municipal and industrial) is an important topic in the field of biochemistry and biotechnology, as well as in the field of environmental engineering. It has many advantages, such as the simple operation of the basic bioreactor, the potential for the production of valuable bioproducts and efficient wastewater treatment in a short time. However, the biological wastewater treatment also has certain downsides, such as air pollution in places which are near bio-lagoons, and endangering the health of personnel involved in this process. By studying and analyzing data from the reference literature, this paper provides a comprehensive overview of information on microorganisms involved in the wastewater treatment process, the factors with a negative effect on their development, as well as the negative effects of these microorganisms and the biological wastewater treatment process on the environment.
\end{abstract}

Key words: biological wastewater treatment, oleaginous microorganisms, environmental protection, air pollution, health risks

\section{EKOLOŠKI ASPEKTI BIOLOŠKOG PREČIŠĆAVANjA OTPADNIH VODA RAZLIČITIM POSTUPCIMA I MIKROORGANIZMIMA}

Izvod: Biološko prečišćavanje otpadnih voda (komunalnih i industrijskih) značajna je tema u oblasti biohemije i biotehnike, kao i na polju inženjerstva zaštite životne sredine. Ono ima niz prednosti, poput jednostavnog rada osnovnog bioreaktora, potencijala za proizvodnju vrednih bioproizvoda i efikasnog tretmana otpadnih voda u kratkom roku. Međutim, biološko prečišćavanje voda poseduje i određene negativne osobenosti, kao što su

\footnotetext{
${ }^{1}$ MSc Tatjana Vijatov, Dr Gordana Dražić, Singidunum University, 32 Danijelova Street, Belgrade, Serbia ${ }^{2}$ Dr Filip Jovanović, Institute of Forestry, 3 Kneza Višeslava Street, Belgrade, Serbia

Author for correspondence: MSc Tatjana Vijatov, Singidunum University, 32 Danijelova Street, Belgrade, Serbia, +381603447030, tatjanavi44@gmail.com
} 
zagađenje okoline na mestima neposredno oko biolaguna i ugrožavanje zdravlja osoblja koje je uključeno u ovaj proces. Pregledom i analizom podataka iz literature, u ovom radu se daje iscrpan pregled informacija o mikroorganizmima koji su zastupljeni u procesu prečišćavanja voda, faktorima koji negativno utiču na njihov razvoj, kao i negativnim efektima ovih mikroorganizama i biološkog prečišćavanja otpadnih voda na životnu sredinu.

Ključne reči: biološko prečišćavanje voda, eleaginozni mikroorganizmi, zaštita životne sredine, zagađenje vazduha, zdravstveni rizici

\section{INTRODUCTION}

Wastewaters are one of the critical problems of industrial production and urban organization.

There are various kinds of biological systems that can help us restore and maintain the physical, chemical and biological properties of water (C̈ule et al., 2017). For the biological wastewater treatment, using aerobic and anaerobic microorganisms for water purification are two technologies that have been around for a long time and are still used today. Three types of wastewater that can be treated by oleaginous microorganisms are (1) wastewater from the food industry, (2) municipal wastewater (sludge), (3) wastewater from the fermentation industry (Chan et al., 2009). The core of anaerobic-aerobic treatment of organic wastewater is usually activated sludge, which does not involve the activity of only one microorganism, but a complex microbial population consisting of bacteria, fungi, protozoa, metazoa, etc. (Eckenfelder, 1998; Sevior and Blackall, 2012).

The wastewater treatment plant (WWTP) has a bioreactor composed of a single chamber in which the processes of biological removal of organic pollutants take place, together with biological nitrification and denitrification. The sewer is aerated using membrane diffusers that are delivered through separate rotary air blowers. The air is supplied to the grilles by rotary blowers, which are characterized by minimal service time and provide high reliability. The stabilization of excess sludge oxygen leads to the removal of odors and the creation of conditions necessary to achieve a high rate of dehydration of sludge. Next, the sewage with activated sludge flows to the vertical secondary sedimentation tanks, located inside the bioreactor. The treated wastewater is then gravitationally discharged through a flow meter and a collection pipe to the treated wastewater outlet, as well as the receiving water body, which is usually a drainage ditch directed towards a river (Korzeniewska et al., 2009).

These technologies are an important issue for science and practical application since the decomposition of pollutants with the use of indigenous microorganisms in conventional systems for wastewater treatment is not always efficient enough. Thus, the aim of this paper is to identify and present diverse populations of microorganisms used in various industries for the process of biological wastewater treatment, and to assess the extent of dispersion of potential pathogens, their negative impact on the environment and the health risks to the personnel engaged in the implementation of the process. 


\section{MATERIAL AND METHODS}

The paper deals with the issue of biological treatment of three basic types of wastewater, as well as the issue of technologies that have been developed for this purpose. In order to make a comprehensive review of the results obtained in numerous studies - the most relevant literature sources on the researched topic were collected, evaluated, systematized, selected and analyzed. The analytical-synthetic research method was applied to process and present the collected data.

Based on the literature on microbiological air pollution caused by the operation of WWTP, an assessment was made of the dispersion of potential pathogens in terms of negative aspects to the environment and the health status of personnel engaged in the process of biological wastewater treatment.

\section{RESULTS AND DISCUSSION}

\subsection{Oleaginous microorganisms used for biological wastewater treatment}

The treatment of wastewater by oleaginous microorganisms has attracted much attention from many researchers due to its many benefits. Namely, this technology can be carried out in a basic bioreactor and fermenter (which can be used for conventional fermentation), so it does not require much financing in advance. Furthermore, this technology can not only effectively treat wastewater in a short time but can also create certain valuable bioproducts (Huang et al., 2017).

In municipal wastewater, the oleaginous yeast Lipomyces starkeyi was used to remediate sewage sludge, by accumulating lipids, with the lipid content reaching $68 \%$ (Angerbauer et al., 2008). In addition to sewage sludge, it has been determined that the sludge from paper mills can be converted into neutral lipids by the activity of one oleaginous yeast for biodiesel production - Cryptococcus vishniaccii (Deeba et al., 2016). Oleaginous yeast Rhodosporidium kratochvilovae was used as a model organism for its unique ability to utilize pulp and paper industry effluent as a culture medium and to accumulate high quantity of triacylglycerol or neutral lipids as large size lipid droplets $(4.56 \pm 0.24 \mu \mathrm{m})$ within its cellular compartment. The process showed a significant reduction in effluent toxic components, i.e. color (89\%), lignin (94.27\%), phenol (99.6\%), total dissolved solids (84.59\%), biological oxygen demand (BOD) (77.36\%), and chemical oxygen demand (COD) removal (94.22\%) (Patel et al., 2017). Oleaginous yeasts, such as Rhodotorula glutinis, Rhodosporidium toruloides and Criptococcus curvatus, could also be used to treat municipal wastewater (Pirozzi et al., 2013). Another effective strategy for municipal wastewater treatment could be the application of a common culture of different microorganisms, such as oleaginous yeast and algae (Chi et al., 2011). Using the raw biomass gasification wastewater, the bacterium Rhodococcus opacus accumulated $54.3 \%$ of lipids with a wastewater COD removal efficiency of $64 \%$. Moreover, these values were further enhanced to $62.8 \%$ and $74 \%$, respectively, following supplementation of the wastewater with mineral salt media in the ratio 4:1 (Goswami et al., 2017). Raw refinery wastewater was also utilized by the same oleaginous bacterium for converting it into bio-oil via hydrothermal liquefaction of the lipid- 
rich biomass produced during the treatment process. Among the different strategies, the continuous cell recycle system proved efficient in terms of complete removal of COD (99\%) and high lipid production (86\%) at a hydraulic retention time of $16 \mathrm{~h}$ (dilution rate of $0.06 \mathrm{~h}^{-1}$ ) (Paul et al., 2019). In summary, according to Hall et al. (2011) and Huang et al. (2017), a total of nine oleaginous yeasts and one oleaginous bacterium have been used to treat municipal wastewater so far.

Table 1. Biological treatment of different wastewaters by oleaginous microorganisms

\begin{tabular}{|c|c|c|c|}
\hline Wastewater & Microorganisms & $\begin{array}{c}\text { COD } \\
\text { removal } \\
(\%)\end{array}$ & Source \\
\hline \multicolumn{4}{|c|}{ Food industry wastewater } \\
\hline $\begin{array}{l}\text { Wastewater from the } \\
\text { monosodium glutamate } \\
\text { industry }\end{array}$ & Rhodotorula glutinis & 85.51 & Xue et al. (2006) \\
\hline $\begin{array}{l}\text { Olive oil mill } \\
\text { wastewater }\end{array}$ & Lipomyces starkeyi & NA & Yousuf et al. (2010) \\
\hline $\begin{array}{l}\text { Wastewater generated } \\
\text { by potato processing }\end{array}$ & Aspergillus orizae & 74.2 & Muniraj et al. (2013) \\
\hline $\begin{array}{l}\text { Wastewater generated } \\
\text { by soybean processing }\end{array}$ & Chlorella pyrenoidosa & 77.8 & $\begin{array}{l}\text { Hongyang et al. } \\
\text { (2011) }\end{array}$ \\
\hline $\begin{array}{l}\text { Soybean oil refinery } \\
\text { wastewater }\end{array}$ & Trichosporon fermentans & 55 & Qiao et al. (2019) \\
\hline $\begin{array}{l}\text { Wastewater from the } \\
\text { starch industry }\end{array}$ & Rhodotorula glutinis & 80 & Xue et al. (2010) \\
\hline \multicolumn{4}{|c|}{ Municipal wastewater or sludge } \\
\hline Sewage sludge & Lipomyces starkeyi & NA & $\begin{array}{l}\text { Angerbauer } \text { et al. } \\
(2008)\end{array}$ \\
\hline Sludge from paper mills & Cryptococcus vishniaccii & NA & Deeba et al. (2016) \\
\hline $\begin{array}{l}\text { Wastewater from the } \\
\text { pulp and paper industry }\end{array}$ & Rhodosporidium kratochvilovae & 77.36 & Patel et al. (2017) \\
\hline \multirow[t]{3}{*}{ Municipal wastewater } & $\begin{array}{l}\text { Rhodotorula glutinis, Rhorosporidium } \\
\text { toruloides, Cryptococcus curvatus }\end{array}$ & NA & Pirozzi et al. (2013) \\
\hline & A co-culture of oleaginous yeasts and algae & 88 & Chi et al. (2011) \\
\hline & Oleaginous consortium (yeasts and bacteria) & 81 & Hall et al. (2011) \\
\hline \multirow{2}{*}{$\begin{array}{l}\text { Wastewaters from } \\
\text { refineries and biomass } \\
\text { gasification industries }\end{array}$} & \multirow[t]{2}{*}{ Rhodococcus opacus } & 74 & $\begin{array}{l}\text { Goswami et al. } \\
\text { (2017) }\end{array}$ \\
\hline & & 99 & Paul et al. (2019) \\
\hline \multicolumn{4}{|c|}{ Fermentation wastewater } \\
\hline Brewery effluent & Rhodotorula glutinis & NA & $\begin{array}{l}\text { Schneider } \text { et al. } \\
\text { (2013) }\end{array}$ \\
\hline $\begin{array}{l}\text { Wastewater from the } \\
\text { bioethanol industry }\end{array}$ & Rhodosporidium toruloides & 72.3 & Zhou et al. (2013) \\
\hline $\begin{array}{l}\text { Cellulosic ethanol } \\
\text { wastewater }\end{array}$ & Oleaginous yeasts and activated sludge & 83.15 & Zhang et al. (2018) \\
\hline \multirow[t]{2}{*}{ Distillery wastewater } & Cryptococcus curvatus & 80 & \multirow{2}{*}{$\begin{array}{l}\text { Gonzales-Garcia et } \\
\text { al. }(2013)\end{array}$} \\
\hline & Rhodotorula glutinis & 84 & \\
\hline \multirow{3}{*}{$\begin{array}{l}\text { Wastewater from } \mathrm{ABE} \\
\text { fermentation }\end{array}$} & Trichosporon coremiiforme & 68.0 & Chen et al. (2012) \\
\hline & Trichosporon dermatis & 68.2 & Peng et al. (2013) \\
\hline & Trichosporon cutaneum & 68.0 & Xiong et al. (2015) \\
\hline $\begin{array}{l}\text { Riboflavin (B2) } \\
\text { fermentation waste }\end{array}$ & Chlorella pyrenoidosa & 89.2 & Sun et al. (2013) \\
\hline
\end{tabular}

The food industry is very important in modern society. Many branches of the processing industry, such as the olive oil industry, the starch industry (Field et al., 1987), and the monosodium glutamate industry (Liu et al., 2007), generate large 
amounts of wastewater. As a rule, the wastewater from the food industry has a high ratio of BOD5 and COD, which indicates high fermentability, so it is possible to treat them by conventional anaerobic digestion (Hassan and Nelson, 2012). Many studies show that oleaginous microorganisms can also be used to purify wastewater from the food industry. For example, the oleaginous yeast $R$. glutinis was used to produce microbiological oil in wastewater generated by the production of monosodium glutamate, with COD removal reaching as high as $85.51 \%$, but the lipid yield was low (less than $0.25 \mathrm{~g} / \mathrm{l}$ ) (Xue et al., 2006). Still, the lipid yield can be significantly increased by adding glucose to the process (Xue et al., 2008). On the other hand, the oleaginous yeast L. starkeyi has been used to purify the wastewater generated in the olive oil mill, with the formation of lipids suitable for biodiesel production (Yousuf et al., 2010). The oleaginous fungus Aspergillus orizae was used to treat the wastewater generated by potato processing, with the COD removal accounting for $74.2 \%$ (Muniraj et al., 2013). In addition, it has been found that the wastewater from soybean processing can be used to cultivate the oleaginous microalga Chlorella pirenoidosa, so that the COD removal amounts to almost $80 \%$ (Hongiang et al., 2011). The wastewater from the starch industry was used in one study as a feedstock for microbiological lipid production, by means of yeast $R$. glutinis, with the results indicating the possibility of industrial application of oleaginous microorganisms for wastewater treatment (Xue et al., 2010). Finally, a fungus from the genus Paecilomyces with high flocculating activity, that can flocculate the oleaginous yeast Trichosporon fermentans, was used to reduce the organic matter in SOR (standard oxygen requirement) wastewater and to produce microbial oil. Under the optimum conditions, the flocculation percentage of Paecilomyces sp. against T. fermentans from SOR wastewater reached $95 \%$ and the removal of COD and oil content in the fermented SOR wastewater reached $55 \%$ and $53 \%$, respectively (Qiao et al., 2019).

Large amounts of wastewater are also generated after fermentation. In the biological wastewater treatment in the fermentation industry, the anaerobic-aerobic method based on activated sludge is usually used with the implementation of special equipment (Lu et al., 1999; Pant and Andoleya, 2007). Recently, it has been established that oleaginous microorganisms can be used to treat wastewater from various fermentation industries. Thus, the waste from the brewery was used as a fermentation substrate for the simultaneous accumulation of microbiological oil and carotenoids, by means of the oleaginous yeast Rhodotorula glutinis (Schneider et al., 2013). In addition, oleaginous yeast Rhodosporidium toruloides was used to treat bioethanol wastewater, with the COD removal, yeast biomass and lipid content $72.3 \%, 3.8 \mathrm{~g} / \mathrm{l}$, and 34.9\%, respectively (Zhou et al., 2013). Oleaginous yeasts $R$. glutinis and Cryptococcus curvatus were used to treat wastewater from distilleries, with the COD removal accounting for about $80 \%$ (Gonzales-Garcia et al., 2013). Similar to ethanol fermentation, ABE (acetone-butanol-ethanol) fermentation also generates a significant amount of wastewater after treatment. It has been found that oleaginous microorganisms can treat wastewater of $\mathrm{ABE}$ fermentation so that the removal of COD amounts to almost 70\% (Chen et al., 2012; Peng et al., 2013; Xiong et al., 2015). Other wastewaters from the fermentation process can also be treated using oleaginous microorganisms. For instance, the oleaginous microalga $C$. pirenoidosa was used for the remediation of fermentation eluates of riboflavin (B2), 
with the COD removal being as high as almost 90\% (Sun et al., 2013, In: Huang et al., 2017). Finally, a strategy for lipid production through coupling oleaginous yeasts and activated sludge biological methods by the cultivation of $R$. glutinis in cellulosic ethanol wastewater was also used. Under optimal conditions in wastewater medium (dilution ratio of 1:2 and glucose supplement of $40 \mathrm{~g} / 1$ ), the maximum biomass and lipid content, as well as the lipid yield, reached $11.31 \mathrm{~g} / 1,18.35 \%$, and $2.08 \mathrm{~g} / \mathrm{l}$, with the associated removal rates of COD, total organic carbon (TOC), $\mathrm{NH}_{4}{ }^{+}-\mathrm{N}$, total nitrogen (TN) and total phosphorous (TP) reaching 83.15\%, 81.81\%, 85.49\%, $70.52 \%$, and $67.46 \%$, respectively. In contrast, cellulosic ethanol wastewater treated by the anaerobic-aerobic biological process resulted in the removal of COD, $\mathrm{NH}_{4}{ }^{+}-$ $\mathrm{N}$, TP, and TN reaching $67.55 \%, 94.17 \%, 90.16 \%$, and $48.89 \%$, respectively (Zhang et al., 2018).

An overview of oleaginous microorganisms, used for the treatment of industrial and municipal wastewater, is shown in Table 1.

From the discussion above, it is clear that conventional anaerobic-aerobic biological treatment has a great total removal of COD from industrial and municipal wastewaters (greater than 80\%, and sometimes even 90\%). In contrast, in the case of biological wastewater treatment by oleaginous microorganisms, the removal of COD is usually relatively low - less than $80 \%$. As a result, these technologies are considered less competitive with other technologies that have industrial applications. Therefore, in order to achieve the industrialization of wastewater treatment by oleaginous microorganisms, the most important task these technologies are facing is to increase the efficiency of COD removal to meet water quality standards.

\subsection{Inoculated microorganisms}

The results of many studies in the literature suggest that, in the activated sludge systems, bioaugmentation can improve the performance of contaminated water treatment by adding external microorganisms with a high degradation capacity of specific pollutants (e.g., Van Limbergen et al., 1998; Yu and Mohn, 2002; El Fantroussi and Agathos, 2005). However, the ecological background (different natural life forms living in communities within a biotope inoculated with an exogenous inoculum) is a major obstacle to the successful performance of bioremediation with such inoculum. In terms of survival, activity, and migration, the relationship of the inoculated microorganism with new biotic and abiotic environments may be crucial to the outcome of any bioaugmentation strategy. There is an increasing amount of information in the literature that the best way to overcome such environmental barriers is to identify microorganisms from the same ecological niche with those present in the contaminated area that is being treated (e.g., El Fantroussi and Agathos, 2005; Thompson et al., 2005).

The design of a single inoculum of the bioaugmentation strategy involves isolation of individual strains of controlled origin, in order to determine which of them show special abilities of decomposition of various pollutants in wastewater. However, the decomposition ability of the whole microbial consortium is usually greater than the ability of any strain in it, because it often depends on the mutual interaction that takes place in microbial consortia (Huban and Plowman, 1997). Microorganisms selected for inoculum formation should be able not only to break 
down the target pollutants, but also to be competitive with other microorganisms, compatible with the indigenous microbial community, and complementary and/or synergistic for the degradation of effluents (Yu and Mohn, 2002).

\subsection{Assessment of the degree of microbiological air pollution in WWTPs}

The number of microorganisms in the air is one of the basic indicators of atmospheric pollution. The character and effect of microorganisms on the environment depend on their initial concentration in the sewage, development phase, emission threshold, wastewater treatment technology, aeration techniques and meteorological and environmental conditions. Microorganisms, which are transferred from the sewer to the air, by aerosol, are subjected to certain conditions that can prevent their development. Some of them die quickly, mainly from drying out or from exposure to excessively high or low temperatures and/or solar radiation. However, other microorganisms are equipped with specific mechanisms that allow them to fight against adverse environmental conditions that inhibit their biological activity (Andersen and Frisvad, 2002; Agranovski et al., 2003).

To assess microbiological air contamination in WWTPs, and the potential exposure hazard to workers and people living in their immediate surroundings, many authors have studied the bioaerosols in and/or near these plants.

In Poland, Filipkowska et al. (2000) studied the emission levels of microbiological pollutants from the wastewater treatment plant in Bartoszyce. The results of the study showed that aeration tanks constitute a significant source of biological aerosol emissions. However, considerably smaller amounts of microorganisms were emitted into the atmosphere from wastewater-collection posts and secondary settling tanks. In addition to this study, Breza-Boruta and Paluszak (2007) carried out microbiological research of bioaerosols in the Municipal Sewage Treatment Plant in Torun. The concentration of selected bacteria, fungi and actinomycetes in the atmospheric air was estimated in the vicinity of sand catchers, aeration chambers and maturing compost piles, as well as $100 \mathrm{~m}$ beyond the treatment plant. It was found that the air at the test stands showed different degrees of microbiological pollution. The largest bioaerosol emission sources were the sand catcher and the maturing compost storage facility. Specifically, the total number of bacteria and fungi amounted to a maximum of $104 \mathrm{CFU} / \mathrm{m}^{3}$, and of actinomycetes $103 \mathrm{CFU} / \mathrm{m}^{3}$. The bacteria of the genus Pseudomonas (fluorescent subgroup) occurred at all the stands throughout the study except December. The number of Escherichia coli and bacteria of the genera Enterococcus and Salmonella remained at the very low level of about $101 \mathrm{CFU} / \mathrm{m}^{3}$, and of all these bacteria only faecal streptococci D-type were isolated beyond the treatment plant.

The study done by Michałkiewicz et al. (2011) dealt with microbiological air pollution around wastewater treatment plants in Słupca, Kostrzyń, and Września, and the Complex Wastewater Treatment and Wastes Composting Plant in Grodzisk Mazowiecki. The results showed that the largest group of microorganisms in the monitored air were psychrophilic and mesophilic bacteria and microscopic fungi. The number of psychrophilic bacteria ranged from 78 to $225,000 \mathrm{CFU} / \mathrm{m}^{3}$, the number of mesophilic bacteria varied in the range from 0 to $195,000 \mathrm{CFU} / \mathrm{m}^{3}$, and 
the fungi from 0 to $65,700 \mathrm{CFU} / \mathrm{m}^{3}$ of air. The number of other bacteria (Staphylococcus, Pseudomonas fluorescens, and coliforms) ranged from 0 to 87,500 $\mathrm{CFU} / \mathrm{m}^{3}$. The authors detected a great number of bacteria and fungi near sewage aeration tanks, places of sludge disposal, and grit chambers. A change in air pollution has been noted depending on the season and climatic conditions (wind strength in particular).

The most notable study was conducted by Korzeniewska et al. (2009). The authors collected air samples at five locations in the WWTP area, and at five locations around the plant, and at one control location. The sampling sites were selected where the emission of bacterial aerosol and dust was potentially the highest, taking into account the wind direction (sampling along the wind direction), as well as the distance from the plant fence. In this study, special attention was paid to faecal bacteria from the family Enterobacteriaceae, because they represent a typical sewage microflora. The results of the study showed that the largest number of bacteria from this family is found in the air sampled inside the bioreactor. The great diversity of bacteria in the sewage during the wastewater treatment phase was then reflected in the air samples collected inside the bioreactor, outside the bioreactor (under the roof), as well as at the outlet of the treated sewage leading into the drainage ditch. Species belonging to the genera Pantoea and Serratia were predominant on the fence, and near the plant, while Escherichia vulneris, Enterobacter sakazakii and Klebsiell sp. were found further from the WWTP. However, no mannitol positive bacteria of the genus Staphylococcus were observed in the analyzed sewage and air samples. The results of mycological analyzes of the air samples collected within the WWTP indicated a higher number of mold species than it was the case with yeasts and filamentous fungi. Numerous fungi, which could be harmful in the natural human environment, were sporadically discovered during the summer, near the bioreactor. Namely, species of the genera Alternaria, Aspergillus, Cladosporium, Mucor, Oidium, Penicillium, Absidia, Actinomucor and Botritis have been identified in the WWTP area, as well as in its surroundings. Among the yeasts that predominated in sewage were species of the genera Candida, Cryptococcus, and Rhodotorula, isolated mainly from air sampled near the grate chamber and within the bioreactor itself. The genera Candida and Cryptococcus were also present in the vicinity of the WWTP. The significant statistical differences in the number of investigated groups of microorganisms were observed between air samples collected in summer and during autumn in relation to those obtained in winter and spring. Their highest mean number was determined in air sampled in summer (except actinomycetes, psychrotrophic and hemolytic bacteria, which were most abundant in spring, as well as yeasts and molds that were most abundant in autumn), while the lowest number was recorded in winter and/or in spring. No significant statistical differences in the number of these microorganisms were detected between the air samples collected from different locations. As already mentioned, the highest concentrations of bacteria from the Enterobacteriaceae family, which ranged from $2.0 \times 10^{5}$ to $4.0 \times 10^{7} \mathrm{CFU} / \mathrm{cm}^{3}$, were found in the air inside the bioreactor, its vicinity, as well as near the grate chamber. The high diversity of bacteria from this family (including Shigella spp., Iersinia enterocolitica, Escherichia coli and Clebsiella pneumoniae ozaenae) may indicate a health risk for plant personnel in case of prolonged exposure time. However, no increased emissions of the analyzed groups 
of microorganisms were found outside the WWTP, which also applied to faecal bacteria (Escherichia coli and Clebsiella pneumoniae ozaenae). Purified sewage water was dominated by yeasts and yeast-like fungi.

A quantitative and qualitative analysis of airborne microorganisms near a WWTP was also conducted by Grisoli et al. (2009) in Italy. Six sites were selected as air sampling sites. Near the facilities, mesophilic bacteria, psychrophilic bacteria and microfungi showed the highest median concentrations of 307.5, 327.5, and 257.5 $\mathrm{CFU} / \mathrm{m}^{3}$, respectively. The contamination index - global index of microbial contamination $\left(\mathrm{GIMC} / \mathrm{m}^{3}\right)$ showed mean values of 4058.9 in summer and 439.7 in winter and the contamination index - amplification index showed values of 4.5 and 1.1 in the same seasons, respectively. Controlling the seasonal effect, mesophilic bacteria, Pseudomonas spp. and Enterobacteriaceae showed a significant decline in concentration with respect to upwind air samples and with increasing distance.

In China, Yang et al. (2019) collected air samples from various treatment facilities of a typical WWTP. Concentrations of airborne bacteria varied in a wide range $\left(23-4878 \mathrm{CFU} / \mathrm{m}^{3}\right)$. It was found that the main emission sources of airborne bacteria were treatment facilities with aeration, mechanical agitation, and located indoors. For treatment facilities located indoors, higher percentages of airborne bacteria were associated with wastewater and sludge, while more airborne bacteria were originated from the ambient air for outdoor installations. Opportunistic pathogens (e.g., Micrococcus, Bacteroides, Chryseobacterium, Pseudomonas and Acinetobacter) were detected in airborne bacteria.

Based on the analyzed data from the literature, it may be argued that the studied facilities do not pose a hazard in respect of the tested bacteria emissions (Breza-Boruta and Paluszak, 2007). However, even if these plants do not represent a potential risk for nearby populations, they may pose a potential health risk for workers (Grisoli et al., 2009). According to Yang et al. (2019), inhalation is the main pathway for on-site exposure of workers to airborne bacteria. Thus, due to the presence of opportunistic pathogens, strict control measures should be employed in WWTPs to reduce infection risks. Research data have shown that coliform bacteria represent a good indicator of microorganisms' emissions from sewage into the air (Michałkiewicz et al., 2011). In relation to this, Korzeniewska et al. (2009) stated that covering the aeration chambers significantly reduces the formation of aerosols and the number of microorganisms that is present in the air inside the plant and in its surroundings.

\section{CONCLUSION}

Based on the data from the reference literature, the following conclusions can be drawn:

- The usual solution for the wastewater problem is to use the so-called cocultures of microorganisms. Activated sludge is one such example of a natural population of microorganisms. Biodegradation of organic materials can also be achieved by the co-culture method. Another way to overcome this environmental problem is to identify microorganisms from the same ecological niche as those that exist in the contaminated area which is being treated;

- With conventional anaerobic-aerobic biological treatment, the total 
removal of COD from industrial and municipal wastewaters can be greater than $80 \%$, and even $90 \%$. In contrast, in the case of biological wastewater treatment by oleaginous microorganisms, we have relatively low removal of COD - usually less than $80 \%$. For this reason, these technologies are less competitive with other technologies with industrial applications. Thus, to achieve the industrialization of wastewater treatment using oleaginous microorganisms, the most important task these technologies are facing is to increase the efficiency of COD removal in order to meet the standards for water quality.

- The degree of air pollution in WWTPs, as well as their surroundings, is reflected by faecal bacteria from the family Enterobacteriaceae, which represent the typical sewage microflora. Thus, their number should be monitored in order to accurately determine the effects of the plant on the natural environment and human health;

- The main sources of bioaerosol emissions in the area of a WWTP are the bioreactor and the grate. The great diversity of species and the increased number of bacteria of the Enterobacteriaceae family, including pathogenic and opportunistic bacteria, found in the air emitted in the bioreactor, may mean that the health of the personnel spending longer periods in or near the bioreactor could be at risk. Still, covering the aeration chambers significantly reduces the formation of aerosols and the number of microorganisms present in the air of the plant and its surroundings;

Future research should focus on the development of the wastewater treatment technologies using the co-culture methods, a combination of chemical or physical treatments, control and adaptation of the fermentation processes, as well as by other methods.

\section{REFERENCES}

Agranovski, V., Ristovski, Z., Hargreaves, M., Blackall, P. J. and Morawska, L. (2003): Performance evaluation of the UVAPS: Influence of physiological age of airborne bacteria and bacterial stress, J. Aerosol Sci., 34: 1711-1727

Andersen, B. and Frisvad, J. C. (2002): Characterization of Alternaria and Penicillium species from similar substrata based on growth and different temperature $\mathrm{pH}$ and water activity, Syst. Appl. Microbiol., 25: 162-172

Angerbauer, C., Siebenhofer, M., Mittelbach, M. and Guebitz, G. M. (2008): Conversion of sewage sludge into lipids by Lipomyces starkei for biodiesel production, Bioresour. Technol., 99(8): 3051-3056

Breza-Boruta, B. and Paluszak, Z. (2007): Influence of water treatment plant on microbiological composition of air bioaerosol, Polish J. Environ. Stud., 16(5): 663-670

Chan, Y. J., Chong, M. F., Law, C. L. and Hassell, D. G. (2009): A review on anaerobicaerobic treatment of industrial and municipal wastewater, Chem. Eng. J., 155: 1-18

Chen, X. F., Huang, C., Xiong, L., Chen, X. D. and Ma, L. L. (2012): Oil production on wastewaters after butanol fermentation by oleaginous yeast Trichosporon coremiiforme, Bioresour. Technol., 118: 594-597 
Chi, Z., Zheng, Y., Jiang, A. and Chen, S. (2011): Lipid production by culturing oleaginous yeast and algae with food waste and municipal wastewater in an integrated process, Appl. Biochem. Biotechnol., 165(2): 442-453

Čule, N., Lučić, A., Dražić, D., Popović, V., Veselinović, M., Brašanac-Bosanac, Lj. and Mitrović, S. (2017): Construction of floating treatment wetlands for remediation of polluted waters, Sustainable Forestry, 75-76: 1-12

Deeba, F., Pruthi, V. and Negi, Y. S. (2016): Converting paper mill sludge into neutral lipids by oleaginous yeast Cryptococcus vishnianccii for biodiesel production, Bioresour. Technol., 213: $96-102$

Eckenfelder, W. (1998): Activated Sludge. Process Design and Controll. CRC Press. Cleveland

El Fantroussi, S. and Agathos, S. N. (2005): Is bioagmentation a feasible strategy for pollutant removal and site remediation? Curr. Opin. Microbiol., 8: 268-275

Field, J. A., Lettinga, G. and Geurts, M. (1987): The methanogenic toxicity and anaerobic degradability of potato starch wastewater phenolic amino acids, Biol. Wastes., 21(1): 37-54

Filipkowska, Z., Janczukowicz, W., Krzemieniewski, M. and Pesta, J. (2000): Microbiological air pollution in the surroundings of the wastewater treatment plant with activated-sludge tanks aerated by horizontal rotors, Polish J. Environ. Stud., 9(4): 273-280

Gonzales-Garcia, Y., Hernandez, R., Zhang, G., Escalente, F. M., Holmes, W. and French, W. T. (2013): Lipids accumulation in Rhodotorula glutinis and Cryptococcus curvatus growing on distillery wastewater as culture medium, Environ. Prog. Sustain. Energy, 32(1): 69-74

Goswami, L., Namboodiri, T. M. M., Vinoth Kumar, R. V., Pakshirajan, K. and Pugazhenthiac, G. (2017): Biodiesel production potential of oleaginous Rhodococcus opacus grown on biomass gasification wastewater, Ren. Ener., 105: 400-406

Grisoli, P., Rodolfi, M., Villani, S., Grignani, E., Cottica, D., Berri, A., Picco, A. M. and Dacarro, C. (2009): Assessment of airborne microorganism contamination in an industrial area characterized by an open composting facility and a wastewater treatment plant, Environ. Res., 109: 135-142

Huban, C. M. and Plowman, R. D. (1997): Bioaugmentation: Put microbes to work, Chem. Eng. J., 104(3): 74-84

Hall, J., Hetrick, M., French, T., Hernandez, R., Donaldson, J., Mondala, A. and Holmes, W. (2011): Oil production by a consortium of oleaginous microorganisms grown on primary effluent wastewater, J. Chem. Technol. Biotechnol., 86: 54-60

Hassan, A. and Nelson, B. (2012): Invited review: Anaerobic fermentation of diary food wastewater, J. Dairy sci., 95(11): 6188-6203

Hongiang, S., Yalei, Z., Chunmin, Z., Xuefei, Z. and Jinpeng, L. (2011): Cultivation of Chlorella pyrenoidosa in soubean processing wastewater, Bioresour. Technol., 102(21): 
Huang, C., Mu-Luo, M.-T., Chen, X.-F., Xiong, L., Li, X.-M. and Chen, X.-D. (2017): Recent advances and industrial viewpoint for biological treatment of wastewaters by oleaginous microorganisms, Bioresource Technology, 232: 398-407

Korzeniewska, E., Filipkowska, Z., Gotkowska-Płachta, A., Janczukowicz, W., Dixon, B. and Czułowska, M. (2009): Determination of emitted airborne microorganisms from a BIOPAK wastewater treatment plant, Water Res., 43: 2841-2851

Liu, R., Zhou, Q., Zhang, I. and Guo, H. (2007): Toxic effects of wastewater from various phases of monosodium glutamate production on seed germination and root elongation of crops, Front. Environ. Sci. Eng. China, 1(1): 114-119

Lu, S., Imai, T., Ukita, M., Sekine, M., Fukagawa, M. and Nakanishi, H. (1999): Fermentation wastewater treatment in a membrane bioreactor, Environ. Technol., 20(4): 431 436

Michałkiewicz, M., Pruss, A., Dymaczewski, Z., Jeż-Walkowiak, J. and Kwaśna, S. (2011): Microbiological air monitoring around municipal wastewater treatment plants, Pol. J. Environ. Stud., 20(5): 1243-1250

Muniraj, I. K., Xiao, I., Hu, Z., Zhan, X. and Shi, J. (2013): Microbial lipid production from potato processing waste water using oleaginous filamentous fungi Aspergillus oryzae, Water Res., 47(10): 3477-3483

Pant, D. and Adholeya, A. (2007): Biological approaches for treatment of distillery wastewater: A review, Bioresour. Technol., 98(12): 2321-2334

Patel, A., Arora, N., Pruthi, V. and Pruthi, A. P. (2017): Biological treatment of pulp and paper industry effluent by oleaginous yeast integrated with production of biodiesel as sustainable transportation fuel, J. Clean. Prod., 142(4): 2858-2864

Paul, T., Baskaran, D., Pakshirajan, K. and Pugazhenthiac, G. (2019): Continuous bioreactor with cell recycle using tubular ceramic membrane for simultaneous wastewater treatment and bio-oil production by oleaginous Rhodococcus opacus, Chem. Eng. J., 367: 76-85

Peng, W. F., Huang, C., Chen, X. F., Xiong, L., Chen, X. D., Chen, Y. and Ma, L. (2013): Microbial conversion of wastewater from butanol fermentation to microbial oil by oleaginous yeast Trichosporon dermatis, Renew. Energy, 55: 31-34

Pirozzi, D., Ausiello, A., Zuccaro, G., Sannino, F. and Yousuf, A. (2013): Culture of oleaginous yeasts in dairy industry wastewaters to obtain lipids suitable for the production of II-generation biodiesel, World Acad. Sci. Eng. Technol., 7(4): 53-57

Schneider, T., Graeff-Honninger, S., French, W., Hernandez, R., Merkt, N., Claupein, W., Hetrick, M. and Pham, P. (2013): Lipid and carotenoid production by oleaginous red yeast Rhodotorula glutinis cultivated on brewery effluents, Energy, 61: 34-43

Seviour, R. J. and Blackall, L. (2012): The microbiology of activated sludge. Springer Science \& Business Media. Berlin 
Thompson, I. P., Van der Gast, C. J., Ciric, L. and Singer, A. C. (2005): Bioaugmentation for bioremediation: The challenge of strain selection, Environ. Microbiol., 7: 909-915

Qiao, N., Gao, M., Zhang, X., Du, Y., Fan, X., Wang, L., Liu, N. and Yu, D. (2019): Trichosporon fermentans biomass flocculation from soybean oil refinery wastewater using bioflocculant produced from Paecilomyces sp. M2-1, Appl. Microbiol. Biotechnol., 103: 2821-2831

Van Limbergen, H., Top, E. M. and Verstraete, W. (1998): Bioagmentation in activated sludge: Current features and future perspectives, Appl. Microbiol. Biotechnol., 50(1): 16-23

Xiong, L., Huang, C., Li, X. M., Chen, X. F., Wang, B., Wang, C., Zeng, X. A. and Chen, X. D. (2015): Acetone-Butanol-Ethanol (ABE) fermentation wastewater treatment by oleaginous yeast Trichosporon cutaneum, App. Biochem. Biotechnol., 176(2): 563-571

Xue, F. Y., Zhang. X., Luo, H. and Tan, T. W. (2006): A new method for preparing raw material for biodiesel production, Process Biochem., 41(7): 1699-1702

Xue, F. Y., Miao, J. X., Zhang, X., Luo, H. and Tan, T. W. (2008): Studies on lipid production by Rhodotorula glutinis fermentation using monosodium glutamate wastewater as culture medium, Bioresour. Technol., 99(13): 5923-5927

Xue, F., Gao, B., Zhu, Y., Zhang, X., Feng, W. and Tan, T. W. (2010): Pilot-scale production of microbial lipid using starch wastewater as raw material, Bioresour. Technol., 101(15): 6092-6095

Yang, K., Li., L., Wang, Y., Xue, S., Han, Y. and Liu, J. (2019): Airborne bacteria in a wastewater treatment plant: Emission characterization, source analysis and health risk assessment, Water Res., 149: 596-606

Yousuf, A., Sannino, F., Addorisio, V. and Pirozzi, D. (2010): Microbial conversion of olive oil mill wastewaters into lipids suitable for biodiesel production, J. Agric. Food Chem., 58(15): 8630-8635

$\mathrm{Yu}, \mathrm{Z}$. and Mohn, W. W. (2002): Bioaugmentation with resin acid-degrading bacterium Zoogloea resiniphila DhA-35 to counteract $\mathrm{pH}$ stress in an aerated lagoon treating pulp and paper mill effluent, Water Res., 36: 2793-2801

Zhang, X., Xu, M. L. and Tan, Z. T. (2018): Microbial lipid production and organic matters removal from cellulosic ethanol wastewater through coupling oleaginous yeasts and activated sludge biological method, Biores. Technol., 267: 395-400

Zhou, W., Wang, W., Li, Y. and Zhang, Y. (2013): Lipid production by Rhodosporidium toruloides $\mathrm{Y} 2$ in bioethanol wastewater and evaluation of biomass energetic yield, Bioresour. Technol., 127: 435-440 


\title{
ENVIRONMENTAL ASPECTS OF BIOLOGICAL WASTEWATER TREATMENT BY DIFFERENT METHODS AND MICROORGANISMS
}

\author{
Tatjana VIJATOV, Gordana DRAŽIĆ, Filip JOVANOVIĆ
}

\section{Summary}

Wastewaters are one of the critical problems of industrial production and urban organization. Biological wastewater treatment has many advantages, such as the simple operation of bioreactors, potential for the production of valuable bioproducts and the efficiency of the treatment itself. However, it also has certain downsides, such as environmental pollution and endangering the health of the working personnel. For this reason, this paper provides a comprehensive overview of information on microorganisms involved in the wastewater treatment process, the factors that negatively affect their development and the negative effects of these microorganisms on the environment.

For processing and presentation of collected data from numerous reference sources, the analytical-synthetic method was applied. The results related to the issue of the impact of the wastewater treatment plant (WWTP) on the environment and the personnel engaged in this process are considered.

The results of the research show that by using the conventional anaerobic-aerobic biological treatment, the total removal of COD (chemical oxygen demand) from industrial and municipal wastewater reaches a value of near $90 \%$. In contrast, in the case of biological wastewater treatment by oleaginous microorganisms, there is usually a relatively low removal of $\mathrm{COD}(<80 \%)$. Undoubtedly, this makes the technologies in question less competitive with other industrial technologies. To implement the treatment of wastewater by oleaginous microorganisms on an industrial level, it is necessary to increase its efficiency to remove COD.

In the context of possible air pollution in the area of WWTP, the main sources of bioaerosol emissions are the bioreactor and the grate. The great diversity of species and the increased number of genera of bacteria from the family Enterobacteriaceae indicate that the health of personnel who stay longer in and/or near the bioreactor could be endangered. However, covering the aeration chambers significantly reduces the formation of aerosols, as well as the number of microorganisms present in the air in the closed area of the WWTP and its surroundings.

Future research should focus on the development of wastewater treatment technologies using the co-culture methods, a combination of chemical and physical treatments, as well as by controlling and modifying this process.

\section{EKOLOŠKI ASPEKTI BIOLOŠKOG PREČIŠĆAVANjA OTPADNIH VODA RAZLIČITIM POSTUPCIMA I MIKROORGANIZMIMA}

\author{
Tatjana VIJATOV, Gordana DRAŽIĆ, Filip JOVANOVIĆ
}

\section{Rezime}

Otpadne vode su jedan od kritičnih problema industrijske proizvodnje i gradske organizacije. Biološko prečišćavanje voda ima niz prednosti, poput jednostavnog rada bioreaktora, potencijala za proizvodnju vrednih bioproizvoda i efikasnosti samog tretmana. No, ono poseduje i određene negativne karakteristike, kao što su zagađenje okoline i ugrožavanje zdravlja angažovanog osoblja. Iz tog razloga, u ovom radu se daje iscrpan pregled informacija o mikroorganizmima zastupljenim u procesu prečišćavanja voda, 
faktorima koji negativno utiču na njihov razvoj i negativnim efektima ovih mikroorganizama na životnu sredinu.

Za obradu i prikaz prikupljenih podataka iz brojnih literaturnih izvora, primenjen je analitičko-sintetički metod. Sagledani su rezultati koji se odnose na problem uticaja postrojenja za prečišćavanje otpadnih voda (PPOV) na okolinu i osoblje koje je angažovano u ovom procesu.

Rezultati istraživanja pokazuju da konvencionalnim anaerobno-aerobnim biološkim tretmanom, ukupno uklanjanje HPK (hemijska potrošnja kiseonika) iz industrijskih i komunalnih otpadnih voda dostiže vrednost od $90 \%$. Nasuprot tome, u slučaju biološkog tretmana otpadnih voda oleaginoznim mikroorganizmima imamo relativno nisko uklanjanje HPK (<80\%). Nesumnjivo, to ove tehnologije čini manje konkurentnim drugim industrijskim tehnologijama. Da bi se ostvario tretman otpadnih voda oleaginoznim mikroorganizmima na industrijskom nivou, potrebno je povećati njegovu moć uklanjanja HPK.

Kada je reč o potencijalnom zagađenju vazduha oko PPOV, utvrđeno je da su glavni izvori emisije bioaerosola na području PPOV bioreaktor i rešetka. Veća raznolikost vrsta i povećan broj rodova bakterija iz porodice Enterobacteriaceae ukazuju na to da bi zdravlje osoblja koje duže boravi u bioreaktoru ili u njegovoj blizini moglo biti ugroženo. No, pokrivanje aeracionih komora značajno smanjuje stvaranje aerosola, kao i broj mikroorganizama prisutnih u vazduhu u zatvorenom području PPOV i njegovoj okolini.

Buduća istraživanja treba usmeriti ka razvoju tehnologija prečišćavanja otpadnih voda metodama zajedničke kulture, kombinacije hemijskog i fizičkog tretmana, kao i putem kontrole i prilagođavanja ovog procesa. 